\title{
IN THE END THERE WAS THE BEGINNING: PAGAN COSMOGONIES IN THE AGE OF JUSTINIAN
}

\begin{abstract}
Summary: The conflict between the pagans and the Christian authorities of the Eastern Roman Empire has given birth to numerous polemical discussions among modern commentators, which is due to the fact that our sources on the subject were often biased. The closing of the Neo-Platonic Academy in Athens in 529 has nevertheless been cited as the end of pagan philosophy, even though its last leader, Damascius, would continue his philosophical activity around the Persian border. My paper deals with the persistent reception of one subject that was at odds with the Christian dogma, the cosmogony.

Damascius is also known for his De principiis, a lengthy treaty about the One and the Ineffable that precedes it. Although the work itself is first and foremost an answer to previous Neoplatonists, it is also an extremely valuable source for other lost Pre-Socratic cosmogonies, namely the Orphic ones, which are interpreted alongside other non-Greek creation myths in the final pages of the treatise.

On the other hand, John Lydus provides an intriguing adaptation of such creation myths in De magistratibus reipublicae Romanae, where he combines Platonic and Aristotelian ideas in order to build an explanatory model for the contemporary decline in offices of state. His choice of sources shows, however, that he was likely a pagan himself and that he had professed the official religion in order to avoid persecution. Thus, he bases his argumentation on a pagan cosmogony as a form of resistance against recent changes in Byzantine bureaucracy.
\end{abstract}

Key words: Damascius, John Lydus, Justinian, cosmogony, paganism, Neoplatonism

While the actions of Constantine and Theodosius were vital in establishing Christianity as an accepted and, later, as the official religion of the Roman Empire, one event in particular seems to stand out as the final victory against pagan religion: the closing of the Neoplatonic Academy in Athens as a result of Justinian's laws against pagans, particularly those who were involved in philosophical education or in divination (529 AD). Although this paper will also briefly discuss the caveats that must be taken into consideration when establishing this one moment as the symbolic death of paganism, the main concern lies less in the chronicling of this otherwise complex phenomenon and more in the reception of the ancient cosmogonic myths that were still being cited in this period. There are two main reasons for this choice of subject: the more obvious 
one is that ancient cosmogonies were most often at odds with the Christian dogma, especially since the latter essentially violated the principle of ex nihilo nihil. The other reason is that a good number of otherwise lost Pre-Socratic cosmogonies can be found in the final chapters of a treatise written by the last leader of the Academy in Athens, Damascius. Since he stands at the end of a long tradition of commentaries and theological treatises, it is particularly important to understand why he decides to quote them to begin with. In addition to the matter of Late Neoplatonism, this paper will also discuss the case of Joannes Laurentius Lydus (henceforth John Lydus), the author of a treatise on Roman magistracies in which he also quotes a cosmogony in order to argue his position concerning the history of one of those magistracies.

The importance of Justinian's act was seen with some amount of skepticism by modern historians. For instance, A. A. Vasiliev, the author of an otherwise voluminous history of the Byzantine Empire, only spares one paragraph for this event, claiming that the Neoplatonic Academy was "the last rampart of effete paganism, the decline of which had been already precipitated by the organization of the University of Constantinople in the fifth century" and that Justinian nevertheless "failed to bring about the complete eradication of paganism; it continued to exist secretly in remote localities", the main reason being one of the conditions imposed by the Persian king Chosroes in his peace treaty with Justinian, namely that the philosophers that had escaped to his country be allowed to spend the rest of their lives in peace and safety in the Byzantine Empire. ${ }^{1}$ K. Krumbacher considered the consequences of Justinian's law to be minimal, albeit from a different perspective: the Neoplatonic Academy in Athens was an unimportant part of the vast Greco-Roman world, which meant that its closing was by no means a massive change or a shock. ${ }^{2}$ Similarly, Charles Diehl pointed out that the event had not left much of an impression on its contemporaries. $^{3}$

This is apparently confirmed by the relative lack of detail with which the end of Athenian philosophical teaching is described by contemporary historians. Indeed, only John Malalas' chronicle makes any mention of it, but due to the laws of the genre, he does not delve into the events that led to this prohibition, as pointed out by E. Watts. ${ }^{4}$ His account is worth quoting in full, especially considering its brevity:

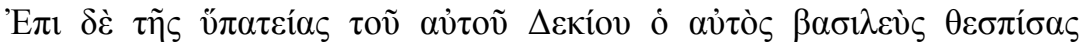

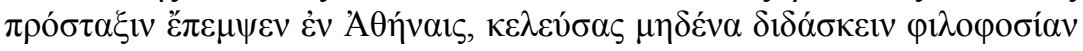

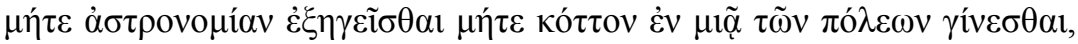

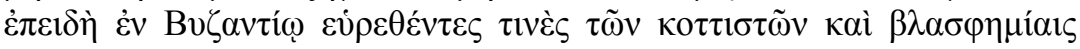

\footnotetext{
${ }^{1}$ VAsilieV, A. A.: History of the Byzantine Empire (324-1453). Madison 1952, 150.

${ }^{2}$ KRUMBACHER, K.: Geschichte der byzantinischen Literatur von Justinian bis zum Ende des oströmischen Reiches (527-1453). München 1897, 5.

${ }^{3}$ DiELS, CH.: Justinien et la civilisation byzantine au VI ${ }^{\text {ime }}$ siècle. Paris 1901, 564.

${ }^{4}$ WATTS, E.: Justinian, Malalas, and the End of Athenian Philosophical Teaching in AD 529. JRS 94 (2004) 168.
} 


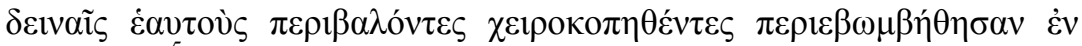
$\kappa \alpha \mu \eta \dot{\mu \lambda} \cos ^{5}$.

During the consulship of Decius, the emperor issued a decree and sent it to Athens ordering that no one should teach philosophy nor interpret astronomy nor in any city should there be lots cast using dice; for some who cast dice had been discovered in Byzantium indulging themselves in dreadful blasphemies. Their hands were cut off and they were paraded around on camels.

In addition to the more general problem caused by Dindorf's reading of $\dot{\alpha} \sigma \tau \rho o v o \mu i ́ \alpha$ as vó $\mu \mu \alpha$, which had led to the interpretation of this law as a ban on philosophy and law schools, the more painful issue is that the text we have today is in fact an epitome. Watts's observation that the epitomator was economical even in describing the Nika Riot is slightly encouraging in that the events in Athens might not have been as uninteresting as the size of the text suggests. ${ }^{6}$ That being said, either Malalas or the author of the epitome considered that the ban on philosophy and astronomy schools and the one on dice were related - as shown by Watts, the latter is to be understood as a form of divination (which, like astronomy and astrology, was of great interest to the Neoplatonists) and not simply as gambling, especially since there is a different law from the same year which prescribes a monetary penalty in case one was guilty of the latter. ${ }^{7}$

While Malalas' version of the events does point to a direct attempt to put an end to the activity of the Neoplatonic Academy by cutting its supply of future students and leaders, the absence of such a law in the Codex Justinianus is, at first glance, perplexing. On the other hand, one should take into consideration that the legal triumph of Christianity against Paganism was a very lengthy process that required many repetitions and confirmations of the same laws.

One of the first examples was given by Constantine's actions: according to Eusebius of Caesarea, not only was he the first emperor to build churches (notably in Jerusalem), but he also ordered the destruction of the temples in Aigai and Heliopolis (although his supposed order to publicly mock the statues has been considered to be an exaggeration belonging to Eusebius). ${ }^{8}$ Constantine also banned sacrifices, but clearly failed to apply this law, since his son Constantius II had to confirm this decision (which was also meant to put an end to the monopoly the pagans had on meat redistribution'), while Theodosius' law from 391 had to specify that no innocent animal should be killed in any ceremony and that nobody was allowed to enter temples

\footnotetext{
${ }^{5}$ Malalas, Chronicle 18. 47. I have quoted the emendated Greek text and the translation from WATTS (n. 4) 171.

${ }^{6}$ WATTS (n. 4) 172.

${ }^{7}$ WATTS (n. 4) 172-174.

${ }^{8}$ CAMERON, A.: The Reign of Constantine, AD 306-337. In Bowman, A. K. - GARNSEY, P. Cameron, A. (eds.): The Cambridge Ancient History. Vol. XII. Cambridge 2005, 100.

${ }^{9}$ Evans, J. A. S.: The Age of Justinian - The Circumstances of Power. London 1996, 66.
} 
to worship pagan idols. ${ }^{10}$ A very similar law can be found 32 years later, although it is quite notable that it is meant for pagans "although we don't think there are any left" (quamquam iam nullos esse credamus). ${ }^{11}$ Through his law from 451, emperor Marcianus declares that the temples that had previously been closed should not be reopened and that whoever is caught making sacrifices or libations should lose all his belongings, ${ }^{12}$ while in 472 , emperor Leo demands that no man should attempt to act on any of those pagan superstitions that were prohibited to men, especially since it is well known that such audacity is in itself a crime. ${ }^{13}$ According to Evans, the emperors were actually reluctant to have pagan citizens turn against them, especially since they did their duties towards the state and were generous in their donations to civic enterprises, but that these laws were mostly the result of the influence of the Church. ${ }^{14}$

Watts claims that Justinian, while not immune to such pressure, "was explicit about his desire" to exclude laws against divination from his compilation of law, which would explain why Malalas' account is not confirmed by other legal sources. ${ }^{15}$ On the other hand, there is a different law that is conserved in the Codex Justinianus, namely one that prohibits unbaptized pagans from teaching and receiving a salary repeated failure to comply resulting in exile and the confiscation of property. Additionally, pagan children would be required to follow Christian education. ${ }^{16}$ The law is different in several specific points: in this case, it is all pagans who are not allowed to teach, while the law described by Malalas concerns all Athenians, regardless of religion, and the teaching of philosophy and astronomy (but not that of grammar and rhetoric). The legal loophole in the latter permitted the continued activity of the Neoplatonic school in Alexandria, led by the equally pagan Olympiodorus. ${ }^{17}$ Watts goes on to make a fine point about the dating of the law described in Codex Justinianus I 1. 10, namely that it is not the direct cause of the closing of the Academy, but rather that it is a pinpointed measure against pagans that dates from 531. Placing it in this particular year would then account for the departure of Damascius and his companions towards Persia, where they had heard rumors that the king, Chosroes, was a lover of philosophy. Indeed, since Chosroes ascended to the throne in September 531, it would be safe to assume that Damascius left the Empire only because of a more recent interdiction, one that directly affected the traditional means of financing their philosophical activities - donations. ${ }^{18}$

${ }^{10}$ Codex Theodosianus XVI 10. 10. I have consulted J. GotTFRIED's edition of the Codex Theodosianus, Leipzig 1736.

${ }^{11}$ Codex Theodosianus XVI 10. 22.

${ }^{12}$ Codex Justinianus I 11. 7. I have used G. HäRTEL and F-M. KAUFMANN's edition and translation of the Codex Justinianus, Leipzig 1991.

${ }^{13}$ Codex Justinianus I 11. 8.

${ }_{15}^{14}$ Evans (n. 9) 67.

${ }^{15}$ WATTS (n. 4) 178.

${ }^{16}$ Codex Iustinianus I 11. 10.

${ }^{17}$ WATTS (n. 4) 178-179.

${ }^{18}$ Watts (n. 4) 180; Athanassiadi, P.: Persecution and Response in Late Paganism: The Evidence of Damascius. JHS 113 (1993) 8-9. 
Damascius himself gives an account of the atmosphere of the times in the Life of Isidore (which was conserved in a summarized form in Photius'Bibliotheca), which describes, among other things, how Isidore of Alexandria (c. 450 - c. 520) left his hometown and came to Athens. Alexandria itself had gone through many clashes between Christians and pagans: George of Cappadocia, the local Arian bishop between 356-361, had ordered the army to attack the Serapeum ("the quintessentially symbolic temple of Egypt", as Athanassiadi puts it ${ }^{19}$ ) and had exiled a iatrophilosopher called Zeno, but had ended up being torn apart by the pagan inhabitants soon after Julian the Apostate became emperor. Although this act of retaliation was never given any further punishment beyond the destruction of the temples in Alexandria in 391, by Isidore's time, "Alexandria, 'the city of foreigners', was at last vindicated in Egyptian eyes and was even viewed as the very epitome of Egyptianism", which meant that Isidore and his masters were philosophers who were well versed in "the Egyptian mysteries". 20

Isidore and Damascius are forced to leave Alexandria following what Damascius calls the "Panopolitan misfortune" from the year 482: the collaboration between the pagan citizens of Alexandria and Pamprepius of Panopolis, who served Illus in his revolt against the Empire. Pamprepius - an Egyptian pagan who had been rejected by the Athenian Neoplatonists - promised that if Illus succeeded in proclaiming Leontius emperor, paganism would finally triumph over Christianity. While the Neoplatonists went on to condemn him and compare him to monsters such as Typhon, the majority of the pagans from Alexandria was convinced by the man's prophecies and by his flamboyant speech, which did not, however, prevent the defeat Illus and Leontius suffered near Antioch in 484. This, in turn, led to yet another wave of persecutions against the pagans. ${ }^{21}$ Although Damascius respected the philosophers who died during those events as martyrs (going so far so as to describe miracles associated to their deaths - for instance, Heraiscus is said to dine with the gods in the afterlife), he did not hesitate to flee with Isidore, who had been hiding in his house during the events. ${ }^{22}$

The fact that they chose to head towards Athens is due, on the one hand, to the existence of the aforementioned philosophical school, which had been founded by Plutarch (d. 432), a successor of other Neoplatonists such as Plotinus, Porphyry, and Iamblichus (who had been active in other cultural centers such as Rome and Alexandria). On the other hand, though, Athens was a very important center of paganism by itself: as pointed out by Alison Frantz, Saint Peter's speech in the Areopagus had had relatively limited success (since he only converted few people, including Dionysus the Areopagite and a woman called Damaris). Furthermore, although the barbarian invasions of 267 had limited Athens to the area to the north of the Acropolis and had destroyed central buildings such as the fortifications or the Agora (which was left in a ruined state until c. 400), Christian authorities had not managed to gain strong foothold in there. In addition to these factors, the Athenian philosophers themselves were

\footnotetext{
${ }^{19}$ ATHANASSIADI (n. 18) 13.

${ }^{20}$ ATHANASSIADI (n. 18) 17.

${ }^{21}$ ATHANASSIADi (n. 18) 19.

${ }^{22}$ ATHANASSIADI (n. 18) 20-21.
} 
often seen as benefactors: Iamblichus, the nephew of the more famous Neoplatonist and Plutarch's teacher, had been praised for his financial support in rebuilding the walls around 400. Moreover, Proclus was shown such respect as an Athenian that historians suppose that the destruction of the temple of Asclepius must have taken place after his death, in $485 .^{23}$

However, Isidore is disappointed with the current state of the Athenian school, which was led by Proclus' successor, Marinus. According to an anecdote, Marinus asked his new student to give his opinion on the new commentary of the Philebus that he was about to publish. After Isidore had told him that Proclus' contribution was good enough, Marinus destroyed his manuscript and only published a commentary of the Parmenides because Proclus had once had a dream that his successor would write one. ${ }^{24}$ Isidore is eventually named honorific leader of the school, but leaves because of his disenchantment with his mediocre contemporaries and, on the other hand, because of the heavy-handed religious turn some of the Athenian philosophers - most notably Hegias - wanted to take. ${ }^{25}$ Damascius did not follow his master on this occasion and took over the school in 515. He used the school's funds - which, as we have mentioned, stemmed from donations - to rebuild the Academy in terms of personnel and actual constructions: thus, he took care to bring the most famous philosophers of the day, in an effort to improve the general quality of teaching in Athens. ${ }^{26}$ His concern with the conservation of a philosophical milieu is equally shown by his exile to Persia, where he leads the delegation of philosophers to the court of Chosroes (who sympathized with them enough to demand their safety in his peace treaty with Justinian, but was otherwise more impressed by the more theatrical Ouranios, as described by Agathias ${ }^{27}$ ).

The fact that Damascius discusses ancient creation myths in his philosophical works is definitely not a novelty, not even in the particular direction it takes. As pointed out by Guthrie, Plato and Aristotle were representative of the two general directions in which philosophers reacted to mythology. Plato (Tim. 40d) speaks of the "theologians" as "sons of gods", who had more insight into such matters because

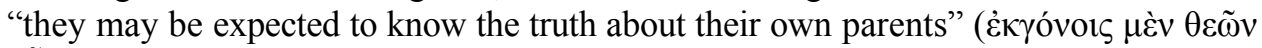

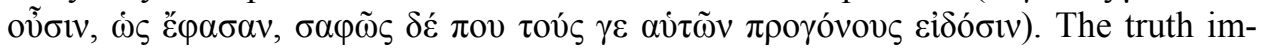
plied by Plato's idea is, according to Guthrie, "that the philosopher read into the theological poems a philosophical meaning which could never have been in the mind of the writer. If we see this process at its best in Plato, we see it at its worst in the Neoplatonists, his commentators". 28 Aristotle's view is summarized as follows: "myth is unnecessary to the philosopher, and can do nothing but confuse the issue". ${ }^{29}$ That be-

${ }^{23}$ FrantZ, A.: From Paganism to Christianity in the Temples of Athens. Dumbarton Oaks Papers 19 (1965) 188-192.

${ }^{24}$ ATHANASSiAdi (n. 18) 11.

${ }^{25}$ WATTS (n. 4) 169.

${ }^{26}$ ATHANASSIADI (n. 18) 23.

${ }^{27}$ Agathias 132. 14 A. The text was published in bilingual form in CAMERON, A.: Agathias on the Sassanians. Dumbarton Oaks Papers 23 (1969-1970) 164-171.

${ }^{28}$ GuTHRIE, W. K. C.: Orpheus and Greek Religion. London 1952, 70.

${ }^{29}$ GUTHRIE (n. 28) 71. 
ing said, it is to Damascius that we owe the only classification of the Orphic theogonies.

In the concluding chapters of his lengthy treaty on The First Principles (in which he refines the theories of his predecessor, Proclus), Damascius discusses the "theo-

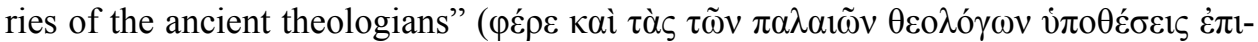
бколи́ $\sigma \omega \mu \varepsilon v$, Damasc. De princ. I 285. 1), starting with "that which is agreed by all

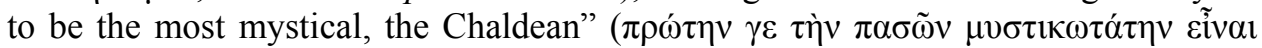

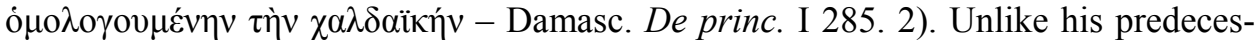
sors, he refers to the Chaldean Oracles as he would to a theory that most disagrees

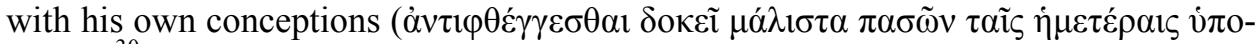
voíars). ${ }^{30}$ While we will not be able to focus enough on Damascius' own theories in this paper, it is worth noting that the point of contention is the unity (according to the Chaldean Oracles) or the multiplicity (i.e. the division into triads) of the intelligible. What is, however, more interesting, is that Damascius states the following regarding the theurgic tradition of the triads:

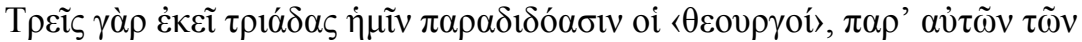

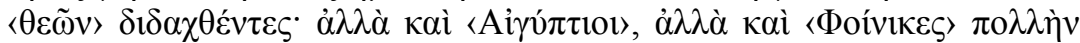

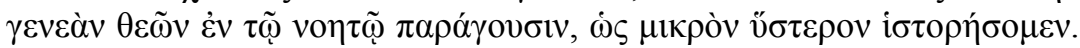

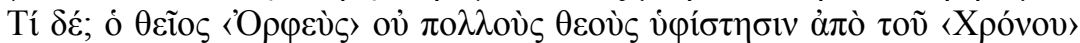

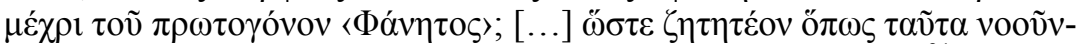

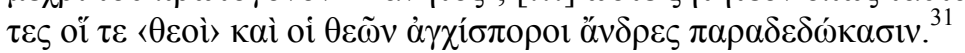

The theurgists have a tradition that there are three triads, a tradition that they have learned from the gods themselves, notwithstanding that the Egyptians and the Phoenicians represent a vast generation of gods in the intelligible, as we shall relate a little later. And what about the following? Does not the divine Orpheus also bring in many gods starting from Chronos and ending with Phanes Protogonos? [...] And therefore we must seek the intellectual meaning of the traditions of the gods and the men who were born near the gods. ${ }^{32}$

In other words, Damascius quotes Orpheus, the Egyptians, and the Phoenicians in order to support his own theory, since their more complex genealogies offer a good parallel to his own subdivisions. As was the case in the various baroque Neoplatonic cosmogonies, the Damascian counterparts of these deities and elements were as follows: one, the one-all, the all-one, the unified, the intelligible being, the intelligible life, the intelligible intellect, the intelligible-intellective, and the intellective. ${ }^{33}$ It is worth men-

${ }^{30}$ Damasc. De princ. I 285. 3. I used L. G. WESTERINK's edition of Damascius, Traité des premiers principes. Vol. III. Paris 1991.

${ }^{31}$ Damasc. De princ. I 285. 5-13.

32 I used S. AHBEL-RAPPE's translation: Damascius, Problems and Solutions Concerning First Principles. New York 2010.

${ }^{33}$ See Betegh, G.: On Eudemus fr. 150 (Wehrli). In BodnÁR, I. - Fortenbaugh, W. (eds.): Eudemus of Rhodes. New Brunswick 2002, 342-343. 
tioning that Damascius postulates an ineffable element that precedes everything else and which, of course, scarcely has any correspondent in his sources.

After his lengthy examination of the Chaldean Oracles, Damascius discusses three versions of the Orphic "theology": the one from the Rhapsodies, ${ }^{34}$ the one described by Hieronymus and Hellanicus (Damasc. De princ. I 317. 15 - I 319. 6), and the one described by the Peripatetic Eudemus (Damasc. De princ. I 319.7 - I 320. 9). Regarding the general nomenclature of these Orphic texts, M. L. West has raised the point that the term "theogony" (which he himself uses throughout his work) is applied, on the one hand, by Clement to distinguish one portion of the Rhapsodies from another $^{35}$ and, on the other hand, in the list of the works of Orpheus in the Suda, where it is claimed that he had written a 1200-line Theogony. According to West, only Fulgentius $^{36}$ and Tzetzes ${ }^{37}$ use it as a title, while Proclus ${ }^{38}$ and Malalas ${ }^{39}$ supposedly use it as a description for Orpheus' "genealogy of gods". 40

In Damascius' account of the Orphic Theogonies, the Rhapsodies are known as

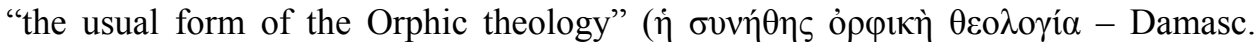
De princ. I 317. 14). These Rhapsodies (alternatively titled Hieros Logos) are a late Hellenistic work synthesizing other theogonies dating back at least to the fifth century, which, according to Carolina López-Ruiz, had come to be "the Orphic theogony par excellence under the Roman Empire and became the main reference point for the Neoplatonists". ${ }^{41}$ Thus, Damascius' version of the Rhapsodic theogony is as follows:

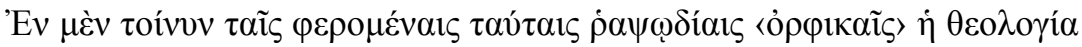

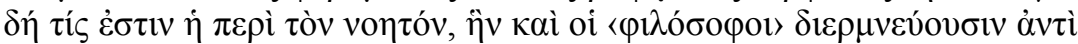

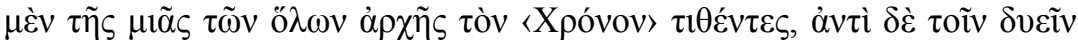

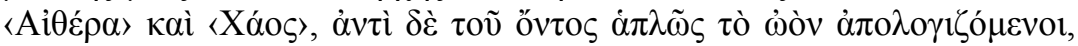

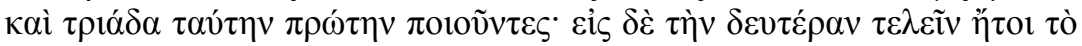

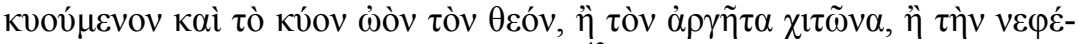

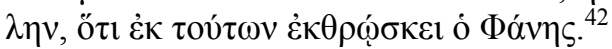

In the Rhapsodies that are circulated under the name Orphic, the following is the theology concerning the intelligible world, a theology that the philosophers also transmit. The theologians put Chronos in the place of the unique principle of wholes, whereas aether and chaos are the two principles [of limit and unlimited], and the egg is in the place of absolute Being, [all of which] constitute their first triad. In the second triad, the last

${ }^{34}$ Damasc. De princ. I.316.10 - I.317.14.

${ }^{35}$ O. F. 149. I used O. KERN's edition of the Orphicorum fragmenta, Berlin 1922.

${ }^{36}$ O. F. 147.

${ }^{37}$ O. F. 173 .

${ }^{38}$ O. F. 128 .

${ }^{39}$ O. F. 62.

${ }^{40}$ West, M. L.: The Orphic Poems. Oxford 1983, 68.

${ }^{41}$ LÓPEZ-RUIZ, C.: When the Gods Were Born. Greek Cosmogonies and the Near East. Cambridge, MA 2010, 134.

${ }^{42}$ Damasc. De princ. I 316.10 - 317. 14. 
term is the egg that is conceived and the egg that gives birth to the god, or the gleaming robe, or the cloud, because Phanes leaps forth from these.

Considering the importance that Damascius gives to this particular version of the Orphic Theogony, it is reasonable to believe that he uses this same source in an earlier reference: "Then great Kronos fashioned the shining egg with the divine aether" ("$\pi \varepsilon \varepsilon-$

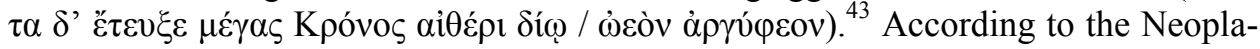
tonist, "the word 'fashioned' shows that the egg is an artifact and not naturally conceived, but every artifact is mixed from two principles at least, that is, matter and

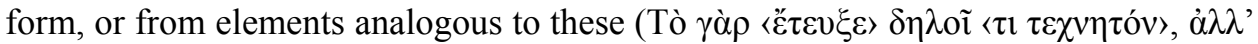

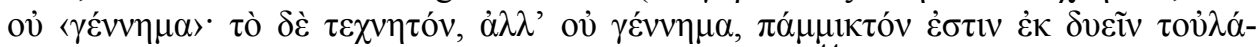

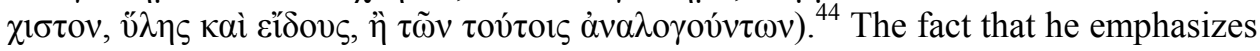
that the verb is $\varepsilon \tau \varepsilon v \xi \varepsilon$ is, likely, more helpful than his own philosophical interpretation, because it means that the quotation is at least precise. This version of the Orphic cosmogony was, in fact, confirmed by the discovery of the Derveni Papyrus, which means that Damascius' depictions of the ancient cosmogonies can be consulted as credible sources, without there being the risk that he should modify them in order to fit his theory. As shown in this paragraph, he never fails to point out where his opinions begin and end.

The other two versions of the Orphic cosmogony give him the pretext to mention the Ineffable element that precedes the One. Thus, in the one he attributes to the otherwise mysterious Hieronymus and/or Hellanicus, he describes the beginning in the following terms:

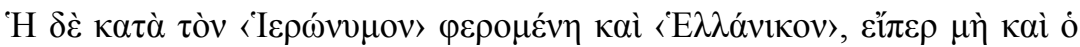

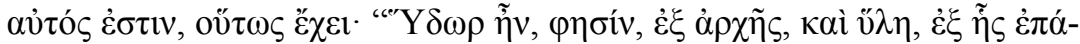

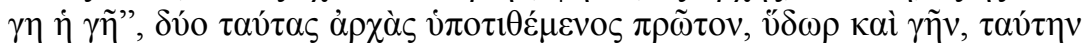

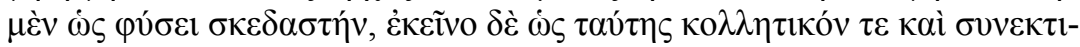

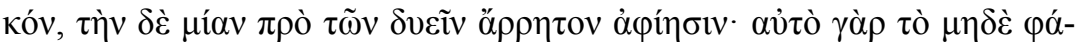

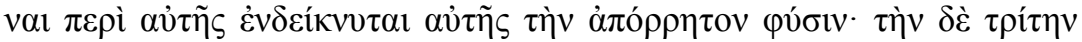

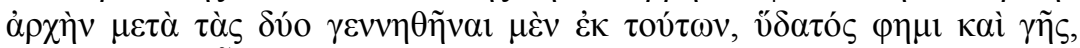

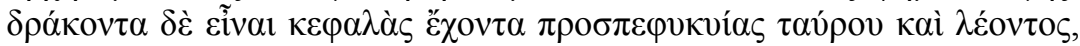

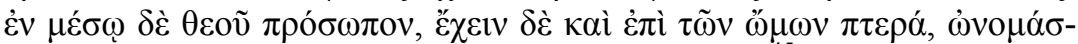

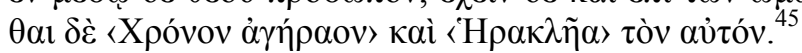

The theology according to Hieronymus or Hellanicus, even if the latter is not the same personage, is as follows. In the beginning, he says, there were water and matter, from which earth was coagulated, and these he establishes as the first two principles, water and earth, the latter as capable of dispersion, and the former as providing coherence and connection for earth. He omits the single principle (before the two) [on the grounds that it is] ineffable, since the fact that [Hieronymus] does not even mention it,

\footnotetext{
${ }^{43}$ Damasc. De princ. I 111. 17.

${ }^{44}$ Damasc. De princ. I 112. 1-3.

${ }^{45}$ Damasc. De princ. I 317. 15-23.
} 
shows its ineffable nature. But as for the third principle after the two, it arose from these, I mean from water and earth, and it is a serpent with the heads of a lion and a bull grown upon it, and in the middle the countenance of a god, and it has wings on its shoulders, and the same god is called Ageless Time, and Heracles.

Damascius inserts an Ineffable element before water and matter (or mud, if we follow Athenagoras' version, which describes a very similar Orphic theogony, without attributing it to the aforementioned writer ${ }^{46}$ ) since it was impossible to suppose that the universe could have started with a pair, and not with the One that all returns to. Rudhardt makes a compelling argument concerning the possibility that "water and mud" should be interpreted as a combination of the two, which would then turn it into a single formless, inert and undifferentiated primordial element. ${ }^{47}$ This interpretation is by no means implausible, since it has been argued that Hesiod's own Chaos was not a chasm, but rather a formless and boundless something that contrasted with Gaia and her successors. ${ }^{48}$ The possibility that the Orphics meant to define this water-and-mud by contrasting it with later elements is strengthened by the presence of the richly described Chronos, who can be said to be "not-formless".

One might argue that Damascius may have found it unnecessary to pursue the possibility that water-and-mud could have been the first element, since it would have been necessary for it to be inexpressible. That being said, when he discusses Acusilaus, he credits him with establishing Chaos as the primordial element "because it is

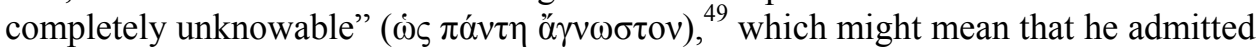
the possibility that one should express the Ineffable with an (admittedly) indefinite concept. When he discusses the non-Greek cosmogonies (via Eudemus), he notes that the Babylonians "seem to have passed over the unique principle of all in silence"

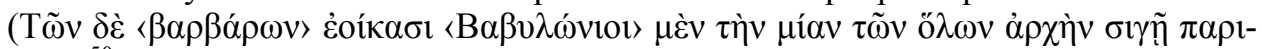
$\dot{\varepsilon} v a 1),{ }^{50}$ while the Egyptian philosophers are said to have "discovered and brought out the truth hidden in certain Egyptian formulations, to the effect that with them the unique principle of the all was celebrated as unknowable darkness, and this was in-

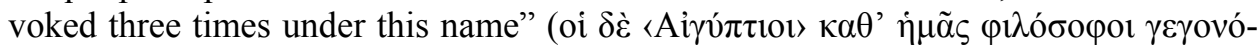

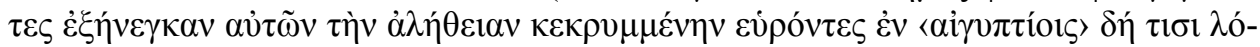

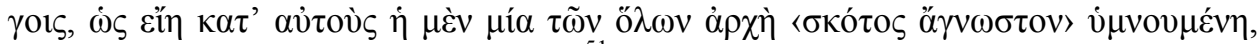

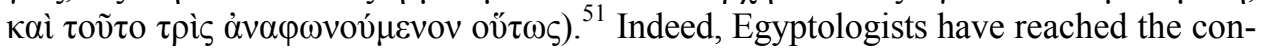
clusion that the primordial deity Nun is a positive expression of the world of the preexistence, ${ }^{52}$ which is also one of the arguments for the aforementioned interpretation of Hesiod's Chaos. Be it as it may, Damascius fulfills several purposes in these final chapters: he conserves the older cosmogonies and proves his own metaphysical theory,

\footnotetext{
${ }^{46}$ See WeSt (n. 40) 183.

${ }^{47}$ RUDHARDT, J.: Le theme de l'eau primordiale dans la mythologie grecque. Bern 1972, 16-17.

${ }^{48}$ MONDI, R.: Xáos and the Hesiodic Cosmogony. HSPh 92 (1989) 28.

${ }^{49}$ Damasc. De princ. I 320. 10.

${ }^{50}$ Damasc. De princ. I 321.1.

${ }^{51}$ Damasc. De princ. I 323. 16 - 324. 2.

${ }^{52}$ BICKEL, S.: La cosmogonie égyptienne avant le Nouvel Empire. Göttingen 1994, 31.
} 
while also openly contradicting Christian dogma. As can be seen, he never attempts to discuss (or even discredit) the Christian Genesis, although his idea of an ineffable primordial element might be meant to diminish the importance of the monotheistic God to begin with - it would be impossible for the creator ex nihilo to be the absolute first entity in the universe and for him to be knowable to humans.

In the concluding chapter to her detailed study of the various forms of Neoplatonism, Sara Rappe notes that: "although the broad outlines of what we today might call a philosophical system can be seen in many of the philosophers who today fall under this sobriquet, the fact remains that the Neoplatonists themselves traced their philosophical genealogy in strikingly different ways. A time span of three centuries makes an unbroken succession of teachers and students an unlikely way to account for the cohesiveness of the tradition". 53 And yet, despite the many contradictions between the various generations of Neoplatonists - at least those who brought consistent contributions, unlike the ones who ended up disappointing Isidore - Damascius seems to be aware of the existence of a longer tradition, one that he had to conserve in spite of the administrative efforts to put an end to it.

The lengthy tradition of Neoplatonism might explain Damascius' depiction and commentary of older cosmogonies, but it comes with an important limitation, namely that this tradition was all but removed by means of Justinian's laws - in other words, Damascius would have had the last word concerning pagan cosmogonies. And yet, two decades after his exile and return, pagan cosmogonies were used in an unlikely manner by an equally unlikely author: John Lydus, the author of a treatise on the history of the empire's administration from the foundation of Rome to the reign of Justinian, On the Magistracies of the Roman State.

Born around 490 in the chief city of Lydia, John Lydus left his hometown in 511 following an extensive education (which included learning Latin, which he would later teach at the State University of Constantinople) and headed for Constantinople, where he was eventually offered a position on the judicial staff of the eastern Praetorian Prefecture. Although he was fairly prosperous under the patronage of his fellow countryman for the following two decades, the appointment of John the Cappadocian (who came from the financial side of the department) as eastern Praetorian Prefect between 531 and 541 brought a change in fortunes. His new superior implemented a series of reforms that favored his former colleagues over John. ${ }^{54}$ In his autobiography, John Lydus describes his disillusion in the following terms: "when Fortune, not as formerly, began to be displeased with learned men, I came to detest the service and ceded myself entirely to books". 55

Indeed, he starts writing antiquarian works in the early 540s, although he does nevertheless manage to reach the highest-ranking post on the judicial side by the end

\footnotetext{
${ }^{53}$ RAPPE, S.: Reading Neoplatonism. Non-discursive Thinking in the Texts of Plotinus, Proclus and Damascius. Cambridge 2000, 231.

${ }^{54}$ KELLY, Chr.: John Lydus and the Eastern Praetorian Prefecture in the Sixth Century AD. Byzantinische Zeitschrift 98/2 (2005) 431-432.

${ }^{55}$ Joannes Lydus, De Mag. 3. 28. I used A. C. BANDY's edition of Ioannes Lydus, On Powers or The Magistracies of the Roman State (De Magistratibus reipublicae Romanae). New York 2013.
} 
of his career in 552, which earns him praise as a man who was prouder of his status as a learned man than of his bureaucratic position. ${ }^{56}$ It is after his retirement that he starts writing his most famous and best-conserved work, On the Magistracies, which is a semi-autobiographic defense of the traditional prefecture in the guise of a historical treatise.

Although he dedicates the entire third book to his autobiography and the prefecture, the second book contains a sudden reference to a cosmogonic myth:

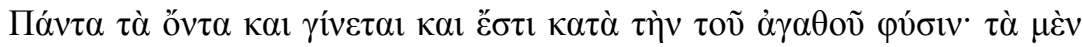

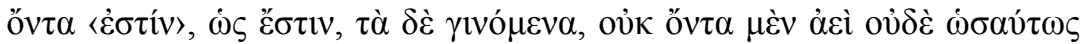

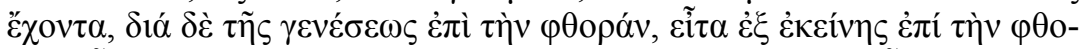

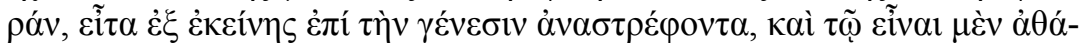

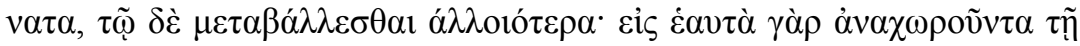

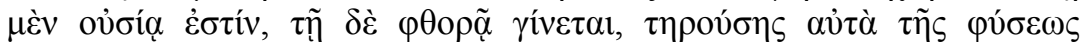

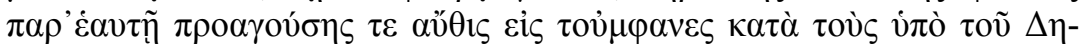

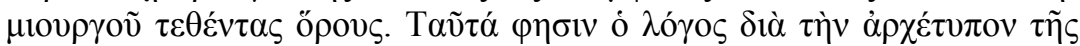

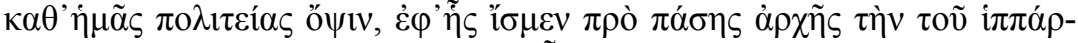

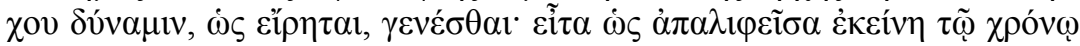

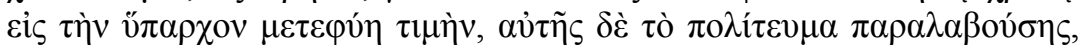

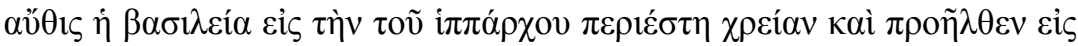

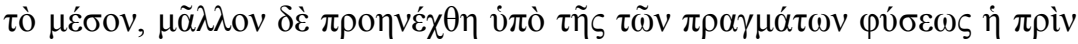

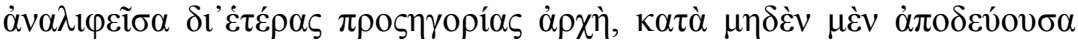

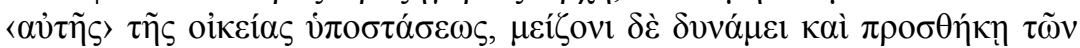

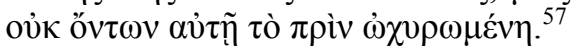

All beings both come into existence and exist in accordance with the nature of the good. The beings exist, as they exist, but those coming into existence do not always exist nor exist in the same manner but revolve through generation to corruption, then from corruption, nature keeping them with itself and bringing them forth again into manifestation in accordance with the standards established by the Creator. Reason asserts these principles about the original aspect of our government, in which we know that the powerful office of the cavalry commander was instituted, as I have said, before any magistracy. Then, when it had been wiped away in the course of time, it was transformed into the prefecture, but, after the latter had taken over the government, the imperial office was reduced again to the need of the cavalry commander and the previously wiped away magistracy emerged publicly through another name or rather was brought forth by the nature of public affairs, in no respect lacking its very own substantial nature but fortified with greater power and the addition of features which formerly it did not have.

\footnotetext{
${ }^{56}$ Joannes Lydus, De Mag. 3. 30.

${ }^{57}$ Joannes Lydus, De Mag. 2. 23.
} 
Whereas Damascius made a point of quoting older cosmogonies in order to argue his points, John Lydus quotes his own version, which was based on a mix of his own interpretation of Plato and, on the other hand, Aristotle's De generatione et corruptione. ${ }^{58}$ In his analysis of De magistratibus, Maas considers that John Lydus uses some philosophical terminology "that he did not understand very well" to create "a carefully considered, though eccentric, theory of decline and restoration"59 and concludes later on that he was a Christian with ambiguous ties to Christianity and, most notably, a " 'Sunday philosopher' who in his writings tried to integrate the formal studies of his youth with his own professional experience". ${ }^{60}$ If we take Lydus' text at face value, it would simply seem that this is just a late and somewhat harmless application of pagan culture.

However, if one takes into consideration that Lydus had had a 40-year career in the Byzantine bureaucracy by the time he wrote his De magistratibus, it might seem odd that he quotes a pagan cosmogony that openly contradicts the Christian dogma by stating that the world was created from a pre-existing "amorphous matter" ${ }^{61}$ without ever referring to Christian writings - or, for that matter, to his own faith. ${ }^{62}$ This did not go unnoticed by later authors: Photius, who reads and summarizes his works, concluded that "in matters of religion he seems to have been an unbeliever. He respects and venerates Hellenic beliefs; he also venerates our beliefs, without giving the reader any easy way of deciding whether such veneration is genuine or hypocritical". ${ }^{63}$ Maas sympathizes with Photius "for not understanding the Justinianic cultural scene", but considers that one should not attempt to define Lydus as either a Christian or a pagan, but that he was a man who used ideas that "had once characterized an anti-Christian pagan polemic, but that in his hands now were completely devoid of immediate religious association". ${ }^{64}$

Anthony Kaldellis considers that Maas, who, like Averil Cameron, assumed that Lydus was an unconventional Christian, “dismisses" Photius' opinion, although, as we have already seen, his opinion was not as clear-cut as Kaldellis puts it. ${ }^{65}$ That being said, he raises several good points that should help us understand why Lydus chose to use that cosmogony in that context.

For one, the concept of religious dissimulation was not unknown to the people of the time: Procopius gives many such examples in his Secret History and, more famously, Julian the Apostate pretended to be a Christian for a few years after his conversion to Platonism. Following these examples, Kaldellis chooses to describe Lydus

\footnotetext{
${ }^{58}$ MAAs, M.: John Lydus and the Roman Past. Antiquarianism and Politics in the Age of Justinian. London 1992, 84.

${ }^{59}$ MAAS (n. 58) 75.

${ }^{60}$ MAAS (n. 58) 97.

61 Joannes Lydus, De Mag. 3. 71.

62 Kaldellis, A.: The Religion of Ioannes Lydus. Phoenix 57.3 (2003) 301.

${ }^{63}$ Phot. Bibl. 180. I used R. HENRY's edition of Photius, Bibliothèque. Vol. II. Paris 1991.

${ }^{64}$ MAAS (n. 58) 3.

${ }^{65}$ KALDELLiS (n. 62) 302.
} 
not as someone who "formally accepted the Christian faith", but as someone who "professed it in order to comply with the laws". 66

Additionally, the man Lydus praises the most in De Magistratibus is Phokas, the praetorian prefect and his superior in 532, whose appointment was to be seen as the result of divine providence, judging by his self-control, liberality, compassion, learning and piety. ${ }^{67}$ Phokas, who apparently sympathized with Lydus more than the others (at the very least more than John the Cappadocian), was a pagan who had come under suspicion on at least two occasions and had eventually committed suicide during Justinian's anti-pagan purge of $545-546$, as pointed out by Kaldellis. ${ }^{68}$ The fact that John Lydus notes Phokas' contribution to the construction of the Hagia Sophia points less to a false belief that Phokas was a Christian and more to his appreciation of a man who gave his support to public works, much in the vein of other rich pagans such as Proclus. The Neoplatonist is an important figure in Lydus' life inasmuch as he was the teacher of Agapios, the man under whom John Lydus studied Plato and Aristotle in 511. His connection to Proclus is, in fact, emphasized in De Magistratibus 3. 26 and, we might note, in his choice of cosmological ideas.

Even though his criticism is a little exaggerated at the outset, Kaldellis does give convincing arguments as to why Christianity and paganism, while not as clearly separated as one may think, could still not be described as "not mutually exclusive", as Maas put it. ${ }^{69}$ Indeed, if we place the writings of Damascius and John Lydus in their respective contexts, we notice that it is always a matter of choice. In the case of Damascius, the reasons are perhaps clearer: he had witnessed the wrongdoings of the Christians in Alexandria and was, nevertheless, the leader of the last rampart of paganism. In writing his cosmogony, he makes an effort to integrate not only the various Neoplatonic doctrines, but also various other ancient cosmogonies. The fact that he does not quote the Christian version would already be quite significant, but his theory of the unknowable Ineffable that precedes any gods or even the One was definitely at odds with the Christian dogma. The incompatibility between metaphysics and human language would doubtlessly put a dent in any attempt to pray to God, who would either be first and unknowable, or knowable, but not first.

John Lydus, on the other hand, was not a clear-cut opponent of Justinian's antipagan policy. Judging by his lengthy career, which went long past the laws that put an end to Neoplatonic activity in Athens, he was never suspected of pagan activity (even though the changes in the praetorian prefecture had done their share of harm to his career). That being said, his works, which were written after his career had reached a certain impasse, show that he may have been closer to the pagan circles than what might have been expected of a Byzantine judicial bureaucrat. In addition to his praise for Phokas, a man who had famously committed suicide during the anti-pagan purge, Lydus showed his affinity towards the old beliefs by basing his arguments for the restoration of the old praetorian prefecture on a cosmology that contradicted the

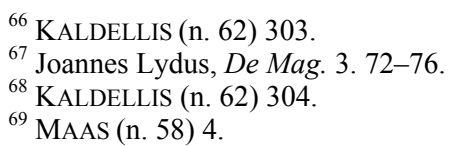


official dogma. The fact that he never even attempts to legitimize it with biblical quotations indicates more than a neutral stance concerning knowledge and learning (especially considering that he compares Isis to "our Asclepius" without so much as a disavowal of such beliefs ${ }^{70}$ ). One point in which both Kaldellis ${ }^{71}$ and Maas ${ }^{72}$ agree is that he likely made use of his interest in antiquities in order to resist the unpleasant realities of the age of Justinian. Indeed, one may consider this to be the conscious choice of a man who had witnessed the many changes that had taken place during this important era of Byzantine history. In other words, the age of Justinian could not possibly have been a time in which paganism and Christianity were not mutually exclusive: even though the law in 529 had not put an end to all philosophical activity in the Byzantine Empire, the decades in which Damascius and Lydus wrote their books should be seen as the last period in which there was a choice between Christianity and paganism, not only on a political level, but also on a philosophical one, namely in one's understanding of how the universe was created.

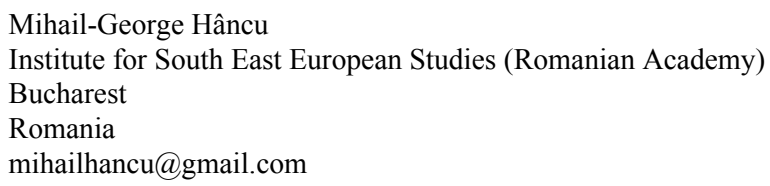

${ }^{70}$ Joannes Lydus, De Mens. 4. 45. For a more detailed discussion of John Lydus' perception of the "Hellenes", see KALDELLIS (n. 62) 307-309.

${ }^{71}$ KALDELLIS (n. 62) 313.

${ }^{72}$ MAAS (n. 58) 4. 